Research Article

\title{
Conservation implications of the mating system of the Pampa Hermosa landrace of peach palm analyzed with microsatellite markers
}

\author{
Doriane Picanço-Rodrigues ${ }^{1}$, Spartaco Astolfi-Filho ${ }^{1}$, Maristerra R. Lemes ${ }^{2,3}$, Rogerio Gribel ${ }^{2,3}$, \\ Alexandre M. Sebbenn ${ }^{4}$ and Charles R.Clement ${ }^{5,1}$ \\ ${ }^{1}$ Laboratório de Evolução Aplicada, Instituto de Ciências Biológicas, Universidade Federal do Amazonas, \\ Manaus, AM, Brazil. \\ ${ }^{2}$ Laboratório de Genética e Biologia Reprodutiva de Plantas, Instituto Nacional de Pesquisas da Amazônia, \\ Manaus, AM, Brazil. \\ ${ }^{3}$ Instituto de Pesquisas Jardim Botânico do Rio de Janeiro, Rio de Janeiro, RJ, Brazil. \\ ${ }^{4}$ Estação Experimental de Tupi, Instituto Florestal de São Paulo, São Paulo, SP, Brazil. \\ ${ }^{5}$ Coordenação de Tecnologia e Inovação, Instituto Nacional de Pesquisas da Amazônia, \\ Manaus, AM, Brazil.
}

\begin{abstract}
Peach palm (Bactris gasipaes) is cultivated by many indigenous and traditional communities from Amazonia to Central America for its edible fruits, and is currently important for its heart-of-palm. The objective of this study was to investigate the mating system of peach palm, as this is important for conservation and breeding. Eight microsatellite loci were used to genotype 24 open-pollinated progenies from three populations of the Pampa Hermosa landrace maintained in a progeny trial for genetic improvement. Both the multi-locus outcrossing rates $(0.95$ to 0.99$)$ and the progeny level multi-locus outcrossing rates (0.9 to 1.0$)$ were high, indicating that peach palm is predominantly allogamous. The outcrossing rates among relatives were significantly different from zero ( 0.101 to 0.202$)$, providing evidence for considerable biparental inbreeding within populations, probably due to farmers planting seeds of a small number of open-pollinated progenies in the same plot. The correlations of paternity estimates were low $(0.051$ to 0.112), suggesting a large number of pollen sources (9 to 20) participating in pollination of individual fruit bunches. Effective population size estimates suggest that current germplasm collections are insufficient for long-term ex situ conservation. As with most underutilized crops, on farm conservation is the most important component of an integrated conservation strategy.
\end{abstract}

Keywords: Bactris gasipaes, bi-parental inbreeding, genetic improvement, genetic conservation, outcrossing.

Received: January 21, 2014; Accepted: July 28, 2014.

\section{Introduction}

The mating system and pollen and seed dispersal mechanisms influence levels of genetic diversity within and among plant populations (Hamrick et al., 1993), contributing to their genetic structure. Hence, studies of the mating system and gene flow are fundamental to support both genetic improvement (Allard, 1960) and conservation (Frankham et al., 2004) programs in plants. Estimates of outcrossing rates and the number of pollen donors within and among progenies and populations can elucidate the genetic structure of these populations, aid in the choice of the most suitable method for estimating genetic parameters,

Send correspondence to Doriane Picanço-Rodrigues. Laboratório de Evolução Aplicada, Instituto de Ciências Biológicas, Universidade Federal do Amazonas, Av. General Rodrigo Octávio 6200, 69077-000 Manaus, AM, Brazil. E-mail: prdoriane@msn.com. and contribute to the study of the inheritance of quantitative traits, selection of superior genotypes, and determination of sample sizes for germplasm collections. Conservation strategies are likely to become more complex and difficult to manage as climate change accelerates during this century (Jarvis et al., 2008; Maxted et al., 2008), and information on the mating system is essential to contribute to this conservation effort.

The peach palm (Bactris gasipaes Kunth) is the only domesticated Neotropical palm (Clement, 1988; Mora Urpí et al., 1997). It was domesticated for its fruit, which are drupes with an edible starchy-oily pulp surrounding the single seed. The fruits are cooked in salted water to eliminate anti-nutritional factors and consumed as snacks throughout its range (Clement, 2008). It was once a staple food for Native American populations from western Amazonia to southern Central America (Mora Urpí et al., 1997). 
Peach palm is increasingly important as a cultivated source of high quality hearts-of-palm, and the respective agribusiness is undergoing strong expansion, mainly in southeastern Brazil, Costa Rica and Ecuador (Clement, 2008; Graefe et al., 2013). Commercial propagation of peach palm uses open-pollinated seeds (Mora Urpí et al., 1997). The majority of seeds available in the market today originate from the Pampa Hermosa landrace, Yurimaguas, Peru (AlvesPereira et al., 2012), as the spineless plants are more easily handled and more productive than those of other landraces (Mora Urpí et al., 1999). The expansion of the hearts-of-palm plantations already constitutes a viable alternative to the unsustainable exploitation of hearts-of-palm from wild palms, such as the endangered Euterpe edulis in the Atlantic forest of southern and southeastern Brazil.

Peach palm phenology is strongly seasonal, with scattered flowering at the end of the Amazonian dry season, a high degree of synchrony at the beginning of the rainy season, and scattered flowering as rains become more abundant (Mora Urpí et al., 1997). The whole flowering period lasts two to three months. The monoecious inflorescences appear in the axils of senescent leaves, each with thousands of unisexual staminate and hundreds of pistillate flowers (Mora Urpí and Solís, 1980). Owing to protogyny, the difference between female and male anthesis in the same inflorescence ( 24 hours), the peach palm is considered to be predominantly outcrossed. There are three pollination mechanisms (Mora Urpí and Solís, 1980): the first and most important is mediated by small curculionid weevils of the genera Andranthobius and Phyllotrox, which have limited flight ranges (100 e $500 \mathrm{~m}$ ); the second is wind; and the third, gravity.

Although outcrossing predominates in the species, self-pollination may occur. A system of genetic self-incompatibility was suggested (Mora Urpí and Solís, 1980), although Clement and Arkcoll (1984) observed that selfcompatibility varied from $0 \%$ to $88 \%$ among individual trees in the Putumayo landrace with controlled pollination. Because peach palm is caespitose (multi-stemmed), there is a possibility of natural self-pollination among stems in the same clump. In addition, Clement (1988) observed that the traditional agricultural practice is to plant various seedlings from open-pollinated progenies in the same plot, which favors mating among relatives. Cole et al. (2007) detected considerable inbreeding $(F=0.105-0.210)$ in peach palm populations belonging to peasant and indigenous communities in northeastern Peru, confirming that traditional practice favors a certain level of biparental inbreeding, even though there is significant gene flow mediated by farmer seed sourcing (Adin et al., 2004). Alves-Pereira et al. (2012) found similar levels (0.156-0.210) within the Pampa Hermosa landrace with a larger sample. Generations of generally unconscious selection for yield will maintain productivity even as heterozigosity decreases due to inbreeding (Hancock, 2004).
Microsatellite markers are considered ideal for studying mating systems as they exhibit simple Mendelian inheritance, are multi-allelic and have co-dominant expression (Powell et al., 1996). Studies on mating systems using microsatellites have been conducted for numerous Neotropical tree species (Ward et al., 2005; Lemes et al., 2007; Carneiro et al., 2007), and pan-tropical (Akuba et al., 2009) and Neotropical palms (Eguiarte et al., 1992; Gaiotto et al., 2003; Conte et al., 2008; Abreu et al., 2011; Nazareno and Reis, 2012). Mating system information is especially important for ex situ conservation. In coconut (Cocos nucifera), the tall varieties are strongly outbreeding while the dwarf varieties are strongly inbreeding, which led to a recommendation of different sample sizes for population conservation (Konan et al., 2008): 90 plants from at least 40 seed parents for tall populations and 45 plants from at least 10 seed parents for dwarf populations. No such study has been done in peach palm to date and this one will provide important new information to guide future improvement and conservation.

The objective of this study was to investigate the mating system of peach palm using microsatellite markers in order to provide information to interpret the genetic structure of progenies and populations of the Pampa Hermosa landrace, and to assist planning in heart-of-palm improvement and ex situ conservation programs. The following questions were addressed: $i$ ) What are the outcrossing, mating among relatives, and paternity correlation rates in the populations? ii) What are the effective number of pollen donors, average co-ancestry coefficients and the variance effective sizes within progenies and populations? iii) What are the conservation implications of this information, both in situ and ex situ?

\section{Materials and Methods}

\section{Plant material}

A progeny trial with 257 open-pollinated progenies collected at peak fruiting season from populations in traditional communities along three rivers (Cuiparillo, Shanusi, Paranapura) in the region of Yurimaguas, Peru, was established in 1991 at the National Research Institute for Amazonia's Tropical Fruit Experimental Station, $38 \mathrm{~km}$ north of Manaus, Amazonas, Brazil. The original collection concentrated on plants with spineless stems and leaf petioles identified in home gardens and swidden plots in traditional and indigenous communities, occasionally with plants collected in the same community within pollination distance of each other. The sampling for our analysis concentrated on a sub-set of the trail with 24 progenies selected for length of the heart-of-palm, including nine progenies from the Cuiparillo River ( $\mathrm{n}=121$ plants), seven from the Shanusi River $(\mathrm{n}=133)$ and eight from the Paranapura River $(\mathrm{n}=105)$ (see Table 1 for individual progeny numbers). 


\section{Microsatellite analysis}

DNA was extracted from $100 \mathrm{mg}$ of apical meristem of a lateral sucker using DNAzol Kit (Life Technologies) and DNA quantity was estimated by comparison with phage $\lambda(100 \mathrm{ng} / \mu \mathrm{L}$, Fermentas) known standard concentrations in $0.9 \%$ ethidium bromide-stained agarose gels. Microsatellite loci amplifications were performed by PCR using eight pairs of primers developed for peach palm by Rodrigues et al. (2004). The PCR mixture $(10 \mu \mathrm{L})$ contained 1X PCR buffer (10 mM TrisHCl, $50 \mathrm{mM} \mathrm{KCl}, \mathrm{pH}$ 8.4), dNTP $(250 \mu \mathrm{M}), \mathrm{MgCl}_{2}(2.5 \mathrm{mM})$, primer forward tail M13 $(0.25 \mu \mathrm{M})$, forward primer M13 label with FAM or HEX or TAMRA fluorochromes $(0.25 \mu \mathrm{M})$, reverse primer $(0.5 \mu \mathrm{M})$, Taq DNA polymerase (Lambda Gene, LGC) (1.5 U), and $15 \mathrm{ng}$ of genomic DNA. The amplifications were performed in an MJ Research PTC-100 thermal cycler according to the conditions described in Rodrigues et al. (2004). Fluorescence-labeled PCR products were analyzed in an automated sequencer (Mega BACE 1000). Alleles were sized using ET-ROX-400 size standard (GE Healthcare, England). Data collection and analysis were performed using Genetic Profiler and Fragment Profiler software (GE Healthcare, England).

\section{Data analysis}

Micro-checker (Van Oosterhout et al., 2004) was used to identify possible null alleles and other genotyping errors. There was a suggestion of the presence of null alleles at some loci in some progenies in one population, which was corrected by elimination of suspected individuals. Possible linkage disequilibrium was evaluated between all loci pairs in each population using a G-test. Statistical significance of $\mathrm{LD}$ was calculated based on 1,000 permutations using the Bonferroni correction for $\mathrm{p}=0.05$. These analyses were run using FSTAT 2.9.3.2 (Goudet, 2002).

Mating system analysis was based on the mixed mating (Ritland and Jain, 1981) and correlated mating models (Ritland, 1989, 2002) using the multilocus mating system program MLTR (Ritland, 2004). The EM (ExpectationMaximization) algorithm was used due to the small number of progenies analyzed per population, as suggested by Ritland (2004). We estimated the following mating system parameters: mean multilocus outcrossing rate $\left(t_{m}\right)$, singlelocus outcrossing rate $\left(t_{s}\right)$, fixation index of maternal parents $(F)$, correlation of paternity $\left(r_{p}\right)$, correlation of selfing $\left(r_{s}\right)$, and the correlation of $t$ among loci $\left(r_{t(l)}\right)$. All parameters were estimated at the population level and $t_{m}$ was also estimated at the individual progeny level. Standard errors (SE) were estimated by bootstrapping over progenies using 10,000 replicates.

Biparental inbreeding was determined by the difference between the multilocus and single-locus outcrossing rates $\left(t_{m}-t_{s}\right)$. The correlation of paternity measures the proportion of outcrossed offspring that are full-sibs, the corre- lation of selfing measures the individual variation in outcrossing rate (Ritland, 1989), the correlation $t$ among loci corresponds to the fraction of inbreeding due to uniparental inbreeding (selfing), and $\left(1-r_{t(l)}\right)$ to the fraction of inbreeding due to the biparental inbreeding.

The effective number of pollen donors was estimated by $\mathrm{N}_{e p}=1 / \mathrm{r}_{p(m)}$ (Ritland, 1989). The coefficient of coancestry among plants within progenies $(\Theta)$ was estimated from the coefficient of correlation of relatedness among plants within progenies $\left(r_{x y}\right)$, following Ritland (1989). In non-inbred diploids, the co-ancestry coefficient is half of $r_{x y}$, so $\Theta=r_{x y} / 2$. The co-ancestry within families was then estimated as

$$
\Theta=0.125\left(1+\hat{F}_{a}\right)\left[4 \hat{s}+\left(\hat{t}_{m}^{2}+\hat{t}_{m} \hat{s} \hat{r}_{s}\right)\left(1+\hat{r}_{p(m)}\right)\right]
$$

where, $s$ is the self-fertilization rate $\left(\hat{s}=1-\hat{t}_{m}\right)$ and $F_{a}$ is the inbreeding coefficient in the parental population (Ritland, 1989). The variance effective population size was estimated according to the expression: $N_{e(v)}=0.5 / \Theta$ (Cockerham, 1969). When multiplied by progeny number, this provides an estimate of $N_{e(v)}$ of the population when two presuppositions are met: $i$ ) the seed trees that produced the progenies are not related; $i i$ ) the seed trees did not cross with one another and received a different pollen gene pool (no overlapping pollen gene pool among fruiting tree) (A.M. Sebbenn, pers. obs.). Given the geographical extent of the original collection expedition, of which roughly $10 \%$ was used here, we believe that these presuppositions are met with very small probability of error.

\section{Results}

The three populations had low levels of linkage disequilibrium with $\mathrm{p}<0.05$, with a mean of $14 \%$ and a range of $7 \%$ to $25 \%$. Since progenies are expected to show disequilibrium, because all of the offspring have at least one allele at each locus from the mother tree, it is impossible to identify other sources of disequilibrium in the populations. Tarazi et al. (2010) showed that this disequilibrium due to progeny-specific genetic expectations does not affect estimates of genetic diversity and structure, mating system or paternity analysis.

The estimates of the multilocus outcrossing rate $\left(t_{m}\right)$ were high for all three populations $(\leq 1)$, but significantly different from 1.0 for the Cuiparillo and Shanusi populations, suggesting a mixed mating system with predominance of outcrossing. The individual multilocus outcrossing rates per progeny were also high in all progenies (based on standard errors, only progeny 7 from the Shanusi population and progeny 2 of the Paranapura population presented values statistically different from 1.0.) of the three populations, with low variation among progenies. The low estimate of the correlation of outcrossing $\left(r_{t}\right)$ agrees with the low variation observed in the outcrossing rates among progenies within populations, confirming the 
Table 1 - Estimates of peach palm mating system parameters in progenies from populations cultivated along three rivers in the distribution of the Pampa Hermosa landrace, near Yurimaguas, Peru.

\begin{tabular}{|c|c|c|c|}
\hline & Cuiparillo & Shanusi & Paranapura \\
\hline \multicolumn{4}{|l|}{ Multilocus outcrossing rate $\left(t_{m}\right)$ in progeny level } \\
\hline Progeny 1 & $1.00(0.00)-[12]$ & $1.00(0.00)-[30]$ & $1.00(0.00)-[10]$ \\
\hline Progeny 2 & $0.95(0.05)-[20]$ & $1.00(0.00)-[27]$ & $0.92(0.08)-[12]$ \\
\hline Progeny 3 & $1.00(0.00)-[14]$ & $1.00(0.00)-[24]$ & $1.00(000)-[12]$ \\
\hline Progeny 4 & $1.00(0.00)-[15]$ & $1.00(0.00)-[17]$ & $1.00(0.00)-[12]$ \\
\hline Progeny 5 & $1.00(0.00)-[12]$ & $1.00(0.00)-[15]$ & $1.00(0.00)-[25]$ \\
\hline Progeny 6 & $0.92(0.01)-[11]$ & $1.00(0.00)-[10]$ & $1.00(0.00)-[12]$ \\
\hline Progeny 7 & $0.94(0.05)-[16]$ & $0.90(0.07)-[10]$ & $1.00(0.00)-[10]$ \\
\hline Progeny 8 & $1.00(0.00)-[11]$ & & $1.00(0.00)-[12]$ \\
\hline Progeny 9 & $1.00(0.00)-[10]$ & & \\
\hline \multicolumn{4}{|l|}{ Mating system parameters in population level } \\
\hline Multilocus outcrossing rate: $t_{m}$ & $0.95(0.93-0.97)$ & $0.98(0.97-0.99)$ & $0.99(0.98-1.00)$ \\
\hline Single locus outcrossing rate: $t_{s}$ & $0.85(0.82-0.88)$ & $0.78(0.74-0.82)$ & $0.88(0.85-0.91)$ \\
\hline Mating among relatives rate: $t_{m}-t_{m}$ & $0.10(0.08-0.12)$ & $0.20(0.17-0.23)$ & $0.11(0.08-0.14)$ \\
\hline Correlation of the estimate of $t: r_{t}$ & $0.07(0.03-0.11)$ & $0.12(0.10-0.14)$ & $0.08(0.06-0.10)$ \\
\hline Correlation of the estimate of $p$ multilocus: $r_{p(m)}$ & $0.07(0.05-0.09)$ & $0.11(0.09-0.13)$ & $0.05(0.03-0.07)$ \\
\hline Correlation of selfing among loci: $r_{t(l)}$ & $0.56(0.49-0.63)$ & $0.39(0.32-0.46)$ & $0.63(0.54-0.72)$ \\
\hline Fraction of apparent selfing due to biparental inbreeding: $1-r_{t}$ & 0.44 & 0.61 & 0.34 \\
\hline Number of pollen donors: $N_{e p}$ & $15.2(11.1-33.3)$ & $9(7.7-10.0)$ & $19.6(14.3-16.7)$ \\
\hline Coefficient of coancestry: $\Theta$ & $0.146(0.139-0.154)$ & $0.144(0.139-0.148)$ & $0.134(0.129-0.139)$ \\
\hline Variance effective size: $N_{e(v)}$ & $3.40(3.25-3.61)$ & $3.48(3.37-3.61)$ & $3.70(3.60-3.88)$ \\
\hline Total variance effective size: $N_{e(v) t}$ & $30.6(29.3-32.5)$ & $24.4(23.6-25.2)$ & $29.6(28.8-31.7)$ \\
\hline
\end{tabular}

[ ] - number of plants in the progeny; () standard errors in the progeny or minimum-maximum in the population.

outcrossed origin of most of the plants in the progenies in these populations. The difference between the multilocus and single-locus $\left(t_{m}-t_{s}\right)$ outcrossing rates was high (minimum $10 \%$ ) and significantly different from zero for all three populations, providing evidence of mating among relatives, especially in the Shanusi population. The fixation index of maternal parents was $\left(F_{a}=0\right)$.

According to the estimated value of the fraction of apparent selfing due to uniparental inbreeding $\left(r_{t(l)}\right)$, the inbreeding in offspring is partially uniparental and partially biparental, with slightly more uniparental inbreeding in Cuiparillo and Paranapura, and slightly more biparental inbreeding in Shanusi. The correlation of paternity $\left(r_{p(m)}\right)$ within the progenies was low $(\leq 0.11)$, suggesting low frequency of full-sibs within progenies and that a large effective number of pollen donors mated with the sampled seed-trees ( 9 to 20 per population). Based on the standard error, the average co-ancestry coefficient $(\Theta)$ among plants within progenies was not significantly different between populations (Table 1). These values were also close to those expected in half-sib progenies $(\Theta=0.125)$, resulting in an estimate of variance effective population size $\left(N_{e(v)}\right)$ close to the value expected in half-sib progenies $\left(N_{e(v)}=4\right)$. Assuming that the seed-trees are not relatives, not mated with one another, and received a non-overlapping pollen pool, the average $N_{e(v)}$ can be multiplied by the number of progenies per population. This yields the total effective population size of 30.6, 26.6 and 29.6 in the Cuiparíllo, Shanusi and Paranapura populations, respectively, and 86.8 for the three populations as a group.

\section{Discussion}

\section{Outcrossing rates}

The high outcrossing rates found for peach palm are similar to those found for other palm species, such as Astrocaryum mexicanum (Eguiarte et al., 1992), Euterpe edulis (Conte et al., 2008), Acrocomia aculeata (Abreu et al., 2011) and Cocos nucifera (Akuba et al., 2009), as well as other tropical tree species (Ward et al., 2005). These high outcrossing rates found for peach palm may be explained by one or more of the following interrelated factors: i) the seeds were collected during the peak of the harvest season (W. Chávez Flores, pers. com., 2007), which would have increased the possibility of numerous plants contributing to cross-pollination, due to the large number of insects visiting the inflorescences during the peak of synchronous flowering three months earlier; ii) the flowering phenology 
of the protogynous peach palm favors exogamy (Mora Urpí and Solís, 1980); and, iii) inbreeding depression killing selfed seeds between the fertilization and sampling stages for genotyping, as observed in other tropical tree species (Gribel and Gibbs, 2002; Hufford and Hamrick, 2003; Naito et al., 2005; Del Castillo and Trujillo, 2008).

\section{Mating among relatives}

The rates of mating among relatives detected here probably arose from the agricultural practice of planting open-pollinated offspring of a few selected seed-trees in the same cultivated plot (Clement, 1988; Cole et al., 2007). This practice produces spatial genetic structure (SGS) within cultivated peach palm and permits mating among relatives, although Adin et al. (2004) reported extremely high gene flow within and between the river systems around Yurimaguas, owing to farmers' seed sourcing practices, which reduces SGS overall. However, for cultivated plants, there is a higher expectation of mating among relatives, as it is common to have only a few seed sources per cultivated area due to farmers' selection practices (Louette, 2000). Still, mating among relatives may also be expected in natural populations of peach palm, as reported in other tropical tree species (Alves et al., 2003; Carneiro et al., 2007; Lemes et al., 2007).

\section{Correlated matings}

The estimated effective number of pollen donors in peach palm was higher ( 9 - 20 per population) than that detected in other palm species, such as Euterpe edulis (maximum 9, Seoane et al., 2005), which may be explained by the fact that the seeds were collected during the peak harvest season or by demographic differences, such as the large population sizes of cultivated peach palm compared with the very fragmented populations of E. edulis. In coconut, effective pollen donor number was very low (1-3), even though outcrossing rates were very high, and was attributed to low flowering synchrony within the plantation (Akuba et al., 2009). High numbers of pollen donors increase the genetic diversity and variance effective population size within progenies. During other parts of the harvest season, however, the number of pollen donors is likely to be lower, so that estimates of variance effective population size within progenies are likely to decrease. This suggests the need to examine the mating system at the beginning and the end of the flowering season when inbreeding may be higher (Vencovsky and Crossa, 1999).

Due to the high outcrossing rate and low paternity correlation, the estimates of the mean coefficient of coancestry within progenies were close to those expected in progenies of half sibs $(0.125)$. This suggests that under random outcrossing in this progeny trial one can expect some biparental inbreeding. However, this inbreeding may be reduced by selection of superior genotypes within progenies, which is likely to reduce within-plot coancestry. Since this trial is being prepared for use as a source of improved seeds (seed nursery), this will be important for both improvement and conservation, as suggested by Cornelius et al. (2006) for a similar trail in Peru.

The Yurimaguas progeny trial is composed almost exclusively of plants from cross-pollination. Consequently, estimation of genetic parameters and selection for heartof-palm production can be based on classical quantitative genetic models applied to exclusively outcrossed species, which presuppose random mating, absence of inbreeding in the parental generation $\left(F_{a}=0\right)$, and progenies composed exclusively of half-sibs (Resende, 2002), considering that the level of inbreeding detected here is very low.

\section{Effective population size}

The estimated total variance effective size $\left(N_{e(v) t}\right)$ of the population samples (maximum 30.6) of these three river basins in the Pampa Hermosa landrace is lower than what is considered acceptable for genetic conservation at the population level (minimum 50, Frankel and Soulé, 1981). However, the high gene flow among these populations (Adin et al., 2004; Alves-Pereira et al., 2012; and Rodrigues DP (2007) PhD Thesis, Universidade Federal do Amazonas, Manaus, AM, Brazil) suggests that conservation should be planned at the landrace level, where the estimated $N_{e(v)}=$ 86.8 is well above the minimum for short term conservation. This estimate is quite close to the tall coconut recommendation (90; Konan et al., 2008), which has similar outcrossing values (Akuba et al., 2009).

\section{Implications for genetic conservation}

Effective size of populations is generally a fraction of the census population, often as low as $10 \%$ (Frankham et al., 2004). In this study, it was slightly more than $24 \%$ (mean $N_{e(v) t} / N=86.6 / 359$ ), likely due to high pollen donor number at peak flowering season. The progeny trials at INPA (Alves-Pereira et al., 2012; Clement et al., 2012) and Embrapa (Kalil Filho et al., 2010; Clement et al., 2012) in Brazil, and in Peru (Cornelius et al., 2006) are adequately dimensioned to handle genetic conservation based on these estimates. The major peach palm germplasm collections in Brazil (375 accessions, with a maximum of 9 plants/accession) and Costa Rica (1,200 accessions with 9 plants) do not have the requisite numbers even of this important landrace, and have much smaller numbers of other landraces; all other collections are smaller (Mora Urpí et al., 1997; Graefe et al., 2013). The main Brazilian collection, at INPA, Manaus, for example, has nearly sufficient census numbers of the Pampa Hermosa, Putumayo and Pará landraces (Clement et al., 2001), but is extremely deficient in all other landraces and wild populations.

In situ conservation is even more problematic. Wild peach palm (B. gasipaes var. chichagui) across southern Amazonia occurs in quite small populations in most places (10-20 plants) in ecosystems that are increasingly frag- 
mented (Clement et al., 2009). It is unlikely that these populations have the high $N_{e(v)}$ found in this study because of low census numbers, but even if they did they are doomed to extinction in fragmented ecosystems because of the lack of gene flow among populations that would keep inbreeding at acceptable levels. Only a few Indigenous Lands and even fewer National Parks and other conservation units contain meta-populations of sufficient size to maintain evolutionary flexibility, although climate change is expected to negate this by the end of the century (Clement et al., 2009).

On farm conservation is less problematic than either in situ or ex situ conservation. Demand for locally popular fruit types remains strong in the pre-Columbian distribution of peach palm (Clement et al., 2004; Graefe et al., 2013) and there are millions of trees in the Neotropics (Clement, 2008), although only about $10 \%$ meet consumer preferences. The expansion of the heart-of-palm agribusiness also provides a conservation bonus, at least for the landraces, such as Pampa Hermosa, that are the genetic bases for the expansion. There are probably 43,000 ha planted in the Neotropics (Clement, 2008), of which at least half is derived from the Pampa Hermosa landrace. Combined with the Peruvian progeny trials (Cornelius et al., 2006), these plantations make Pampa Hermosa the bestconserved peach palm landrace.

As climate change accelerates during the $21^{\text {st }}$ century, both in situ and ex situ conservation of crop and wild relative genetic resources will become both more critical to support agricultural adaptation and more difficult to achieve in the face of alternative demands for human and financial resources for other activities of mitigation and adaptation. Our estimates of the numbers of plants necessary for adequate ex situ population conservation are similar to those in coconut and certainly in most outcrossing tropical trees, which means that ex situ conservation will become continually more difficult for minor crops and other underutilized species. The implications are that on farm conservation will become continually more important or the variety of species that supply the human enterprise will become continually narrower.

\section{Acknowledgments}

We dedicate this study to the memory of Marilene L.A. Bovi, a leader in peach palm research in Brazil until 2006, who contributed important suggestions to this study. We thank the Brazilian Conselho Nacional de Desenvolvimento Científico e Tecnológico (CNPq), Programa do Trópico Úmido, project number 46.9889/00-4, and the Fundação de Amparo à Pesquisa do Estado do Amazonas (FAPEAM), project number $15087 / 2003$, for funding to CRC and SAF, and FAPEAM for a scholarship to DPR, Kaoru Yuyama for access to the progeny trial and its passport data, Izeni Farias and Thomas Hrbek, Universidade Federal do Amazonas, for useful criticism and suggestions to the manuscript, and $\mathrm{CNPq}$ for research fellowships to SAF, MRL, RG, AMS and CRC.

\section{References}

Abreu AG, Priolli RHG, Azevedo-Filho JA, Nucci SM, Zucchi MI, Coelho RM and Colombo CA (2011) The genetic structure and mating system of Acrocomia aculeata (Arecaceae). Genet Mol Biol 35:119-121.

Adin A, Weber JC, Sotelo-Montes C, Vidaurre H, Vosman B and Smulders MJM (2004) Genetic differentiation and trade among populations of peach palm (Bactris gasipaes Kunth) in the Peruvian Amazon- implications for genetic resource management. Theor Appl Genet 108:1564-1573.

Akuba RH, Sangalang JB and Hautea DM (2009) Assessing mating systems of coconut (Cocos nucifera L.) composite variety using microsatellite markers. J Inovasi Gorontalo 4:1-25.

Allard RW (1960) Principles of Plant Breeding. John Wiley \& Sons, New York, 485 pp.

Alves RM, Artero AS, Sebbenn AM and Figueira A (2003) Mating system in natural populations of Theobroma grandiflorum (Willd. ex. Spreng.) Schum., by microsatellite markers. Genet Mol Biol 26:373-379.

Alves-Pereira A, Clement CR and Picanço-Rodrigues D (2012) Genetic divergence among populations and accessions of spineless peach palm of the Pampa Hermosa landrace used in the heart-of-palm agribusiness in Brazil. Genet Mol Biol 35:474-479.

Carneiro FSC, Sebbenn AM, Kanashiro M and Degen B (2007) Low inter-annual variation of mating system and gene flow of Symphonia globulifera in the Brazilian Amazon. Biotropica 39:628-636.

Clement CR (1988) Domestication of the pejibaye palm (Bactris gasipaes): Past and present. In: Balick MJ (ed) The Palm Tree of Life. Biology, Utilization and Conservation. Advances in Economic Botany 6. New York Botanical Garden, New York, pp 155-174.

Clement CR (2008) Peach palm (Bactris gasipaes). In: Janick J and Paull RE (eds) The Encyclopedia of Fruit and Nuts. CABI Publishing, Wallingford, pp 93-101.

Clement CR and Arkcoll DB (1984) Observações sobre autocompatibilidade em pupunha (Bactris gasipaes H.B.K., Palmae). Acta Amazon 14:337-342.

Clement CR, Yuyama K and Chávez Flores WB (2001) Recursos genéticos de pupunha. In: Sousa NR and Souza AGC (eds) Recursos Fitogenéticos na Amazônia Ocidental: Conservação, Pesquisa e Utilização. Embrapa Amazônia Ocidental, Manaus, pp 143-187.

Clement CR, Weber JC, van Leeuwen J, Astorga-Domian C, Cole DM, López LAA and Argüello H (2004) Why extensive research and development did not promote use of peach palm fruit in Latin America. Agrofor Syst 61:195-206.

Clement CR, Santos RP, Desmouliere SJM, Ferreira EJL and Farias Neto JT (2009) Ecological adaptation of wild peach palm, its in situ conservation and deforestation-mediated extinction in southern Brazilian Amazonia. PLoS ONE 4:e4564.

Clement CR, Kalil Filho AN, Modolo VA, Yuyama K, PicançoRodrigues D, van Leeuwen J, Farias Neto JT, Cristo-Araújo M and Chávez Flores WB (2012) Domestication and breeding of peach palm. In: Borém A, Lopes MTG, Clement CR 
and Noda $\mathrm{H}$ (eds) Domestication and Breeding: Amazonian Species. Editora da Universidade Federal de Viçosa, Viçosa, pp 361-392.

Cockerham CC (1969) Variance of gene frequency. Evolution 23:72-84.

Cole DM, White TL and Nair PKR (2007) Maintaining genetic resources of peach palm (Bactris gasipaes Kunth): The role of seed migration and swidden-fallow management in northeastern Peru. Genet Resour Crop Evol 54:189-204.

Conte R, Reis MS, Mantovani A and Vencovsky R (2008) Genetic structure and mating system of Euterpe edulis Mart. populations: A comparative analysis using microsatellite and allozyme markers. J Hered 99:476-482.

Cornelius JP, Clement CR, Weber JC, Sotelo-Montes C, van Leeuwen J, Ugarte-Guerra LJ, Ricse-Tembladera A and Arevalo-Lopez L (2006) The trade-off between genetic gain and conservation in a participatory improvement programme: The case of peach palm (Bactris gasipaes Kunth). Forests Trees Livelihoods 16:17-34.

Del Castillo RF and Trujillo S (2008) Effects of inbreeding depression on outcrossing rates among populations of a tropical pine. New Phytol 177:517-524.

Eguiarte LE, Perez Nasser N and Pinero D (1992) Geneticstructure, outcrossing rate and heterosis in Astrocaryum mexicanum (tropical palm) - Implications for evolution and conservation. Heredity 69:217-228.

Frankel OH and Soulé MS (1981) Conservation and Evolution. Cambridge University Press, Cambridge, 327 pp.

Frankham RJ, Ballou D and Briscoe DA (2004) A Primer of Conservation Genetics. Cambridge University Press, Cambridge, $236 \mathrm{pp}$.

Gaiotto FA, Grattapaglia D and Vencovsky R (2003) Genetic structure, mating system and long-distance gene flow in heart of palm (Euterpe edulis Mart.). J Hered 94:399-406.

Graefe S, Dufour D, van Zonneveld M, Rodriguez F and Gonzalez A (2013) Peach palm (Bactris gasipaes) in tropical Latin America: Implications for biodiversity conservation, natural resource management and human nutrition. Biodivers Conserv 22:269-300.

Gribel R and Gibbs PE (2002) High outbreeding as a consequence of selfed ovule mortality and single vector bat pollination in the Amazonian tree Pseudobombax munguba (Bombacaceae). Int J Plant Sci 163:1035-1043.

Hamrick JL, Murawshi DA and Nason JD (1993) The influence of seed dispersal mechanism on the genetic structure of tropical tree populations. Vegetatio 107-108:281-297.

Hancock JF (2004) Plant Evolution and the Origin of Crop Species. CABI Publishing, Wallingford, 313 pp.

Hufford KM and Hamrick JL (2003) Viability selection at three early life stages of the tropical tree Platypodiu melegans (Fabaceae, Papilonoidae). Evolution 57:518-526.

Jarvis A, Lane A and Hijmans RJ (2008) The effect of climate change on crop wild relatives. Agric Ecosyst Environ 126:13-23.

Kalil Filho AN, Clement CR, Resende MDV, Farias Neto JT, Bergo CL, Yokomizo GK-I, Kaminski PE, Yuyama K and Modolo VA (2010) Programa de melhoramento genético de pupunha na Embrapa, IAC e INPA. Embrapa Florestas Documentos 205:1-34.

Konan JL, Bourdeix R and George ML (2008) Regeneration guidelines: Coconut. In: Dulloo ME, Thormann I, Jorge MA and Hanson J (eds) Crop Specific Regeneration Guidelines. CGIAR System-wide Genetic Resources Programme, Rome, pp 1-10.

Lemes MR, Grattapaglia D, Grogan J, Proctor J and Gribel R (2007) Flexible mating system in a logged population of Swietenia macrophylla King (Meliaceae): Implications for the management of a threatened Neotropical tree species. Plant Ecol 192:169-179.

Louette D (2000) Traditional management of seed and genetic diversity: What is a landrace? In: Brush SB (ed) Genes in the Field: On-farm Conservation of Crop Diversity. Lewis, International Development Research Centre/International Plant Genetic Resources Institute, Boca Raton, pp 109-142.

Maxted N, Kell SP and Ford-Lloyd BV (2008) Crop wild relative conservation and use: Establishing the context. In: Maxted N, Ford-Lloyd BV, Kell SP, Iriondo JM, Dulloo ME and Turok J (eds) Crop Wild Relative Conservation and Use. CAB International, Wallingford, pp 3-30.

Mora Urpí J, Bogantes-Arias A and Arroyo-Oquendo C (1999) Cultivares de pejibaye para palmito. In: Mora Urpí J and Gainza-Echeverria J (eds) Palmito de Pejibaye (Bactris gasipaes Kunth): Su Cultivo e Industrializacíon. Editorial Universidad de Costa Rica, San José, pp 41-47.

Mora Urpí J and Solís E (1980) Polinización en Bactris gasipaes H.B.K., Palmae. Rev Biol Trop 28:153-174.

Mora Urpí J, Weber JC and Clement CR (1997) Peach Palm: Bactris gasipaes Kunth. Promoting the Conservation and Use of Underutilized and Neglected Crops. Institute of Plant Genetics and Crop Plant Research/Gatersleben/International Plant Genetic Resources Institute, Rome, 83 pp.

Naito Y, Konuma A, Iwata H, Suyama Y, Seiwa K, Okuda T, Lee SL, Muhammad N and Tsumura Y (2005) Selfing and inbreeding depression in seeds and seedlings of Neobalano carpusheimii (Dipterocarpaceae). J Plant Res 118:423-430.

Nazareno AG and Reis MS (2012) Linking phenology to mating system: Exploring the reproductive biology of the threatened palm species Butia eriospatha. J Hered 103:842-852.

Powell W, Machray GC and Provan J (1996) Polymorphism revealed by simple sequence repeats. Trend Plant Sci 1:215222.

Resende MDV (2002) Genética Biométrica e Estatística no Melhoramento de Plantas Perenes. Embrapa Informação Tecnológica, Brasilia, 975 pp.

Ritland K(1989) Correlated matings in the partial selfer Mimulus guttatus. Evolution 43:848-859.

Ritland K (2002) Extensions of models for the estimation of mating systems using $\mathrm{n}$ independent loci. Heredity 88:221-228.

Ritland K and Jain S (1981) A model for the estimation of outcrossing rate and gene frequencies using independent loci. Heredity 47:35-52.

Rodrigues DP (2007) Diversidade genética e sistema de reprodução em progênies elites de pupunheira inerme (Bactris gasipaes Kunth) com marcadores microssatélites: Implicações para o melhoramento do palmito. PhD Thesis, Universidade Federal do Amazonas, Manaus.

Rodrigues DP, Vinson C, Ciampi AY, Farias IP, Lemes MR, Astolfi-Filho S and Clement CR (2004) Novel microsatellite markers for Bactris gasipaes (Palmae). Mol Ecol Notes 4:575-576.

Seoane CES, Sebbenn AM and Kageyama PY (2005) Sistema de reprodução em duas populações naturais de Euterpe edulis 
Mart. sob condições de fragmentação florestal. Sci For 69:13-24.

Tarazi R, Sebbenn AM, Mollinari M and Vencovsky R (2010) Mendelian inheritance, linkage and linkage disequilibrium in microsatellite loci of Copaifera langsdorffii Desf. Conserv Genet Res 2:201-204.

Van Oosterhout C, Hutchinson WF, Wills DPM and Shipley P (2004) MICRO-CHECKER: Software for identifying and correcting genotyping errors in microsatellite data. Mol Ecol Notes 4:535-538.

Vencovsky R and Crossa J (1999) Variance effective population size under mixed, self and random mating with applications to genetic conservation of species. Crop Sci 39:1282-1294.

Ward M, Dick CW, Gribel R and Lowe AJ (2005) To self, or not to self A review of outcrossing and pollen-mediated gene flow in Neotropical trees. Heredity 95:246-254.

\section{Internet Resources}

Goudet J (2002) FSTAT (Version 2.9.3.2): A computer program to calculate F-statistics. Université de Lausanne, Lausanne, http://www.unil.ch/dee/home/menuinst/softwares — dataset/softwares/fstat.html (accessed 11 Jul 2014).

Ritland K (2004) Multilocus mating system program - MLTR Version 3.0. University of British Colombia, Vancouver, http://genetics.forestry.ubc.ca/ritland/programs.html (accessed 15 Aug 2006).

Associate Editor: Everaldo Gonçalves de Barros

License information: This is an open-access article distributed under the terms of the Creative Commons Attribution License, which permits unrestricted use, distribution, and reproduction in any medium, provided the original work is properly cited. 